\title{
Ensilability of the tropical grass 'Splenda'
}

\author{
JM Martins \\ Departamento Zootecnia, Universidade Évora, Apartado 94, 7001 Évora Codex, Portugal
}

Irrigated $\mathrm{C}_{4}$ photosynthesis grasses are more productive than $\mathrm{C}_{3}$ grasses in portuguese hot season, due to better use of nitrogen, water, high temperatures and solar radiation.

The aim of this study was to evaluate the ensiling characteristics and limiting factors of 'Splenda' (Setaria sphacelata var. sericea x S. sphacelata var. splendida).

Irrigated 'Splenda' was harvested 10 weeks after the clearing cut when about $50 \%$ of the plants had flowered. Part of the forage was wilted during $24 \mathrm{~h}$. Fresh (FF) and wilted forage (WF), chopped $( \pm 4 \mathrm{~cm}$ ) with a manual guillotine, was sub-sampled for analysis. Additives were added before ensiling.

Five $10 \mathrm{~kg}$ laboratory silos were filled for each treatment and stored during 90 days : Treatment 1 (T1) consisted of ensiled fresh forage, treatment 2 (T2) of ensiled wilted forage, treatment 3 (T3) of ensiled fresh forage to which it was added formic acid (4 ml ADD$\mathrm{F}(\mathrm{B} / \mathrm{kg} \mathrm{FM})$ and treatment 4 (T4) of fresh forage ensiled with Ecosyl $(7.5 \mathrm{mg} / \mathrm{kg} F M)$.

Results obtained were submitted to analysis of variance (Steel and Torrie, 1980, Principles and procedures of Statistics, McGraw-Hill, New York).
Statistical differences between treatments (Table) showed that T4 gave the best results, producing average quality silages. $\mathrm{T} 1, \mathrm{~T} 2$ and T3 gave poorer results, with high $\mathrm{pH}, \mathrm{N}-\mathrm{NH}_{3}$ and ADF and low lactate and IVDM digestibility values.

Considering the percentage of flowered plants and the chemical composition and digestibility values, we may conclude that 'Splenda' was cut in an advanced maturity stage and produced average to poor quality silages. The relatively low number of epiphytic $L A B$, probably a result of cutting height $( \pm 10 \mathrm{~cm})$ and of the fairly aseptic conditions in which forage was handled, may have influenced the fermentation process and lead to the underutilisation of the fermentable plant sugars. The restriction of the fermentation process is evident in T2, where $\mathrm{pH}$ and WS carbohydrates content of the silage were the highest and the lactate content the lowest of all treatments. This fact seems to have been overcome to some extent in T4, where an additive with Lactobacillus plantarum was used.

\begin{tabular}{cccccc} 
FF & WF & T1 & T2 & $T 3$ & $T 4$ \\
$1.90 \times 10^{2}$ & $3.50 \times 10^{2}$ & $1.52 \times 10^{9}$ & $1.87 \times 10^{9}$ & $1.71 \times 10^{9}$ & $3.34 \times 10^{9}$ \\
$2.50 \times 10^{2}$ & $2.00 \times 10^{2}$ & $1.24 \times 10^{2 b}$ & $0.00^{\mathrm{a}}$ & $0.60 \times 10^{2 \mathrm{ab}}$ & $0.40 \times 10^{2 \mathrm{ab}}$ \\
$3.50 \times 10^{5}$ & $4.80 \times 10^{5}$ & $2.04 \times 10^{3}$ & $5.00 \times 10^{3}$ & $2.42 \times 10^{3}$ & $6.60 \times 10^{2}$ \\
20.10 & 41.10 & $18.94^{\mathrm{a}}$ & $38.50^{\mathrm{b}}$ & $20.86^{\mathrm{a}}$ & $20.64^{\mathrm{a}}$ \\
& & $6.03^{\mathrm{C}}$ & $6.13^{\mathrm{C}}$ & $5.70^{\mathrm{b}}$ & $4.49^{\mathrm{a}}$ \\
4.23 & 4.62 & $0.61^{\mathrm{a}}$ & $2.38^{\mathrm{C}}$ & $1.69^{\mathrm{b}}$ & $0.70^{\mathrm{a}}$ \\
1.24 & 1.09 & $1.61^{\mathrm{ab}}$ & $1.07^{\mathrm{a}}$ & $1.57^{\mathrm{ab}}$ & $1.70^{\mathrm{b}}$ \\
50.0 & 42.2 & $51.7^{\mathrm{b}}$ & $67.2^{\mathrm{C}}$ & $40.3^{\mathrm{ab}}$ & $36.3^{\mathrm{a}}$ \\
& & $28.0^{\mathrm{c}}$ & $9.9^{\mathrm{ab}}$ & $12.4^{\mathrm{b}}$ & $5.7^{\mathrm{a}}$ \\
72.1 & 73.7 & $72.3^{\mathrm{ab}}$ & $72.3^{\mathrm{ab}}$ & $79.4^{\mathrm{b}}$ & $67.0^{\mathrm{a}}$ \\
40.3 & 41.4 & $44.4^{\mathrm{ab}}$ & $42.9^{\mathrm{ab}}$ & $46.7^{\mathrm{b}}$ & $39.6^{\mathrm{a}}$ \\
10.9 & 10.7 & $12.6^{\mathrm{ab}}$ & $11.5^{\mathrm{a}}$ & $13.5^{\mathrm{b}}$ & $11.4^{\mathrm{a}}$ \\
& & $0.15^{\mathrm{a}}$ & $0.25^{\mathrm{a}}$ & $0.38^{\mathrm{ab}}$ & $0.61^{\mathrm{b}}$ \\
& & $1.30^{\mathrm{c}}$ & $0.29^{\mathrm{a}}$ & $0.76^{\mathrm{b}}$ & $0.23^{\mathrm{a}}$ \\
& & $0.20^{\mathrm{b}}$ & $0.06^{\mathrm{a}}$ & $0.06^{\mathrm{a}}$ & $0.05^{\mathrm{a}}$ \\
& & $0.76^{\mathrm{c}}$ & $0.07^{\mathrm{a}}$ & $0.36^{\mathrm{b}}$ & $0.41^{\mathrm{b}}$ \\
& & $1.97^{\mathrm{b}}$ & $0.63^{\mathrm{a}}$ & $0.86^{\mathrm{a}}$ & $0.64^{\mathrm{a}}$ \\
& & $46.20^{\mathrm{a}}$ & $48.08^{\mathrm{a}}$ & $48.66^{\mathrm{a}}$ & $54.96^{\mathrm{b}}$ \\
\hline
\end{tabular}

Means in the same row not followed by the same letter differ significantly ( $\mathrm{P} \leq 0.05)$. 